\title{
Dual causes of multiple myeloma
}

\author{
Zaw Min, Zipporah Krishnasami, William J Cook, J Martin Rodriguez
}

\begin{abstract}
Introduction: Patients infected with human immunodeficiency virus (HIV) infection have been living longer secondary to dramatic improvements in their immune status because of highly active antiretroviral therapy (HAART). Consequently, there is an increasing incidence of non-AIDS defining malignancies and chronic diseases in HIV-infected individuals. The hepatitis C virus (HCV) co-infection is highly prevalent in patients with HIV infection. Case Report: We report a patient with HIV and HCV co-infection who presented with multiple myeloma, and explore literature looking for a plausible causal association between multiple myeloma, HIV and HCV infections. Conclusion: Multiple myeloma is not a commonly associated malignancy with HIV and/or HCV infection although hyperglobulinemia is often associated. Clinicians should be aware that multiple myeloma may occur as a non-AIDS defining cancer in HIVinfected individuals and/or as an extrahepatic manifestation in $\mathrm{HCV}$-infected patients.
\end{abstract}

Zaw Min ${ }^{1}$, Zipporah Krishnasami², William J Cook ${ }^{3}$, J Martin Rodriguez ${ }^{4}$

Affiliations: ${ }^{1} \mathrm{MD}$, Infectious Diseases Fellow, Division of Infectious Diseases, University of Alabama, Birmingham, Alabama, USA; ${ }^{2} \mathrm{MD}$, Assistant Professor, Division of Nephrology, University of Alabama, Birmingham, Alabama, USA; ${ }^{3} \mathrm{MD}, \mathrm{PhD}$, Emeritus Professor, Department of Pathology, University of Alabama, Birmingham, Alabama, USA; ${ }^{4} \mathrm{MD}$, FACP, Associate Professor, Division of Infectious Diseases, University of Alabama, Birmingham, Alabama, USA.

Corresponding Author: Zaw Min, MD, Infectious Diseases Fellow, Division of Infectious Diseases, University of Alabama, THT 229, 1530 3rd Avenue South, Birmingham, AL 35294-0006 USA; Ph: 1-205-934-5191; Fax: 1-205-9345155; Email: zawmin@uab.edu

Received: 21 January 2013

Accepted: 21 June 2013

Published: 01 September 2013
Keywords: Multiple myeloma, Human immunodeficiency virus (HIV), Acquired immune deficiency syndrome (AIDS), Hepatitis C infection

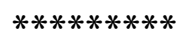

Min Z, Krishnasami Z, Cook WJ, Rodriguez JM. Dual causes of multiple myeloma. International Journal of Case Reports and Images 2013;4(9):489-493.

$* * * * * * * * *$

doi:10.5348/ijcri-2013-09-363-CR-7

\section{INTRODUCTION}

Human immunodeficiency virus (HIV)-infected patients have benefited from dramatic improvements in prognosis and life expectancy because of effective highly active antiretroviral therapy (HAART). The incidence of AIDS-defining neoplasms has consequently decreased [1]. However, non-AIDS defining malignancies and chronic diseases are increasingly being reported in HIVinfected populations [1-3]. Chronic hepatitis $C$ virus (HCV) infection is highly prevalent in HIV-infected patients due to similarities in the epidemiology. Hepatitis $\mathrm{C}$ virus infected patients frequently develop chronic liver disease, but extrahepatic complications have also been reported including HCV-associated B cell tumors [4, 5]. We describe a patient with HIV and HCV co-infection who developed IgG lambda light chain multiple myeloma. We review literature for a possible causal association between multiple myeloma, HIV and HCV infection.

\section{CASE REPORT}

A 47-year-old African-American female co-infected with HIV and HCV presented to our HIV clinic for routine follow-up. She had been diagnosed with HIV and HCV 
infections eight years before. She had been treated with interferon and ribavirin for HCV infection, but she did not complete therapy due to side effects from interferon. Her HIV infection was well-controlled with anti-retroviral therapy (zidovudine, lamivudine and efavirenz) with CD4 count of 1257 cells/ $\mu \mathrm{L}$ and HIV-RNA viral load of less than 20 copies $/ \mathrm{mL}$. She complained of fatigue, diffuse arthralgias and unintentional weight loss $(8 \mathrm{~kg}$ in two months). Physical examination was unremarkable. Her laboratory studies showed normochromic and normocytic anemia with a hemoglobin of $10 \mathrm{~g} / \mathrm{dL}$ (normal range $10.3-15.2 \mathrm{~g} / \mathrm{dL}$ ), elevated serum creatinine at $2.5 \mathrm{mg} / \mathrm{dL}$ (normal range $0.4-1.2 \mathrm{mg} / \mathrm{dL}$ ), and high globulin gap with a serum total protein of $9.6 \mathrm{~g} / \mathrm{dL}$ (normal range 6.0-7.9 g/ $\mathrm{dL}$ ) and a serum albumin of $3.3 \mathrm{~g} / \mathrm{dL}$ (normal range 3.5$5.0 \mathrm{~g} / \mathrm{dL}$ ). An extensive work-up to evaluate the etiology for renal dysfunction was undertaken. A renal sonogram revealed normal-sized kidneys. A 24-hour urine collection showed $2.1 \mathrm{~g}$ of protein. Anti-nuclear antibodies and complement levels were normal and HCV-RNA viral load was 20 million copies/mL with HCV genotype 1a. Serum cryoglobulin was negative. Serum and urine protein electrophoreses showed a monoclonal spike (4.26 g/ $\mathrm{dL}$ ) and immunofixation electrophoreses demonstrated monoclonal IgG with elevated free lambda light chains. Serum free monoclonal lambda light chain was elevated at $3500 \mathrm{mg} / \mathrm{L}$ (normal range $5.7-26.3 \mathrm{mg} / \mathrm{L}$ ). Skeletal survey was negative. The patient underwent a renal biopsy which revealed light chain casts in the renal tubules (Figure 1A-B), confirmed as monoclonal lambda light chain on immunofluorescence (Figure 2). There was no evidence of HIV-associated nephropathy (HIVAN). A bone marrow biopsy showed more than $45 \%$ of plasma cell infiltration (Figure 3). After the diagnosis of IgG lambda light chain multiple myeloma was made, she was treated with nine cycles of initial induction chemotherapy (bortezomib and dexamethasone) followed by autologous hematologic stem cell transplant per the institutional treatment protocol. Subsequently, her serum creatinine improved to $1.1 \mathrm{mg} / \mathrm{dL}$. The patient declined anti-HCV therapy because of her previous intolerance to interferon treatment.

\section{DISCUSSION}

The HIV/AIDS cancer match study, one of the largest epidemiological studies conducted in the United States (US), linked 15 population-based HIV/AIDS and cancer registries in the US. The study analyzed 413,080 HIVinfected persons in 34 US states from 1991 through 2005. During that period, an estimated 79,656 cancers occurred in the AIDS population. It was observed that the incidence of the AIDS-defining malignancies declined markedly over that 14-year period, whereas non-AIDSdefining neoplasms became the predominant type of cancer in HIV-infected persons during the HAART era. Multiple myeloma is one of those non-AIDS-defining
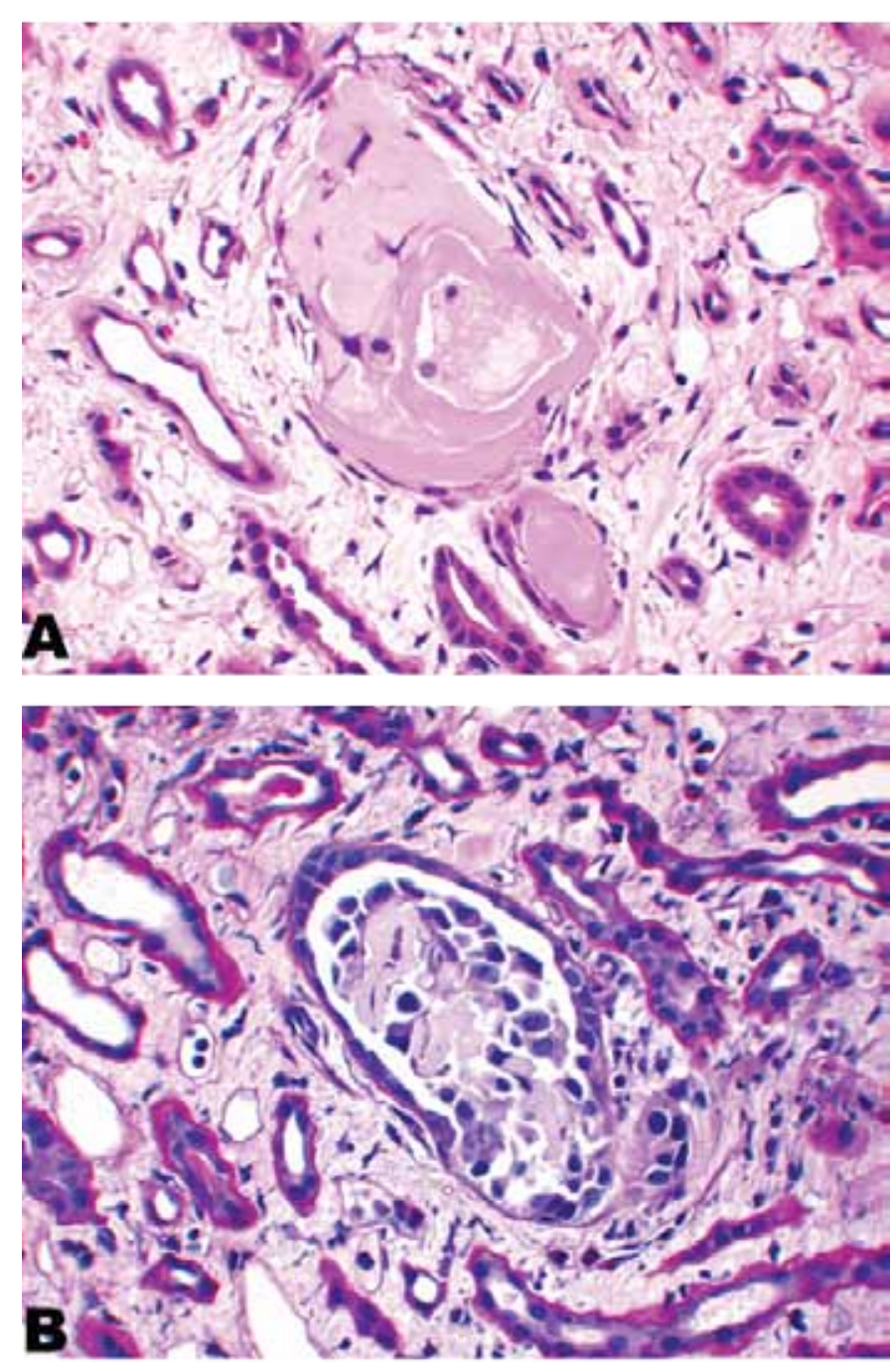

Figure 1: (A) Distal tubule with a large, acellular hyaline cast that has a lamellated appearance (H\&E stain, x200), (B) Dilated tubule with degenerated epithelium and a layer of dehisced cells covering the fragmented cast material (Periodic acid-Schiff hematoxylin stain, x200).

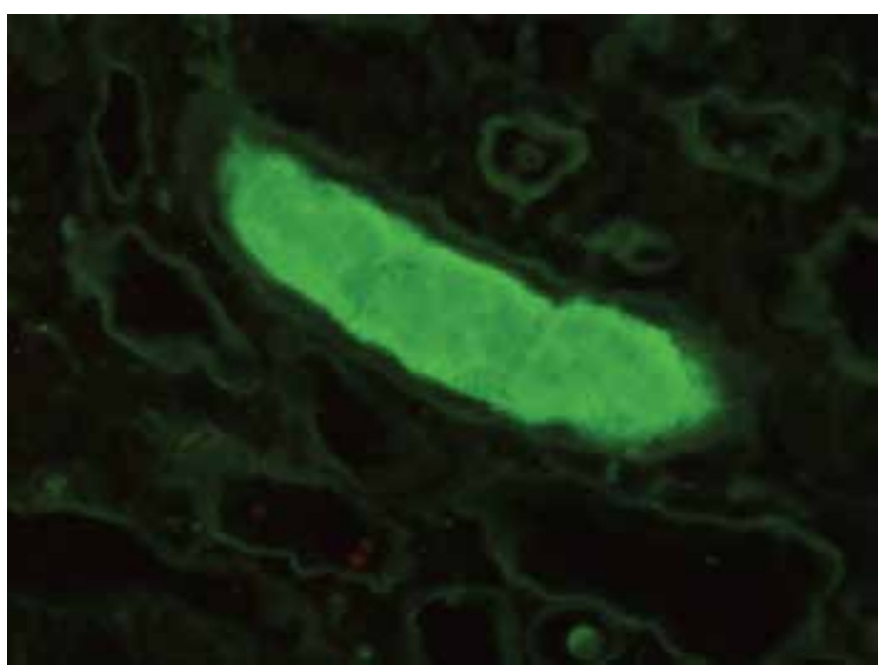

Figure 2: The casts stained strongly positive for lambda light chains. There was no staining for kappa light chains. Fracture lines perpendicular to the long axis of the cast were evident (immunofluorescence stain, x200). 


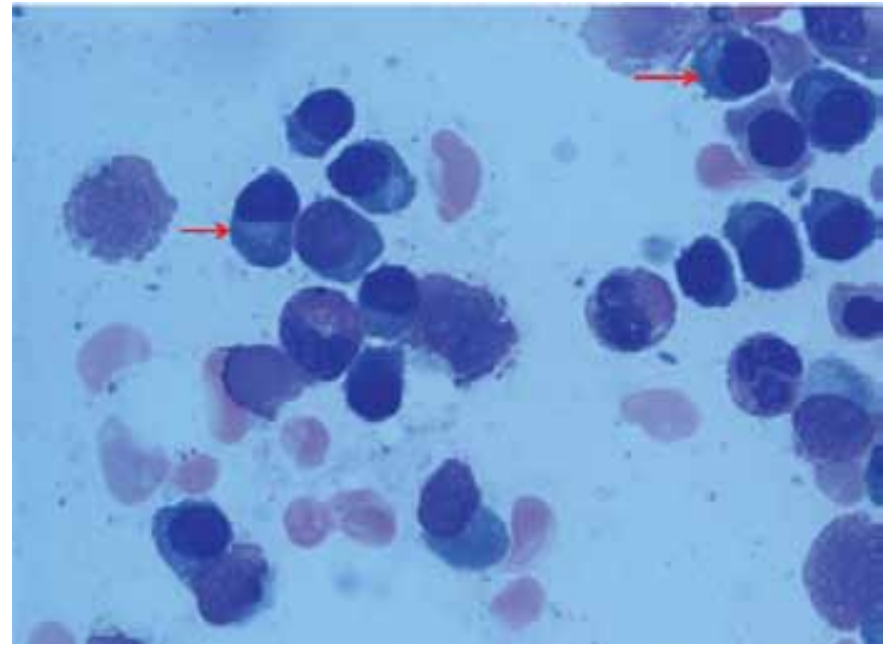

Figure 3: A bone marrow aspirate smear showed $>45 \%$ of plasma cells, evidenced by eccentrically placed nuclei with a marked prinuclear hof, or cytoplasmic clearing (red arrows).

cancers whose incidence has increased recently in HIVinfected individuals [1].

The HIV-infected patients can present with a range of plasma cell disorders, from benign polyclonal hypergammaglobulinemia, or indeterminate monoclonal gammopathy of unknown significance (MGUS) to malignant plasma cell dyscrasias [6]. Multiple myeloma is usually not recognized as a malignancy that is associated with HIV infection. There have been only about 50 reported cases of HIV-infected patients with multiple myeloma in literature since the first case was reported in 1983 [7]. Multiple myeloma has also been reported as the initial clinical manifestation of HIV/AIDS infection [8]. The pathogenesis of multiple myeloma in HIV-infected patients is multifactorial (Figure 4). There are at least two major proposed mechanisms:

(i) a monoclonal paraprotein is specifically directed against the HIV-1 p24 gag antigen [9] and

(ii) continued stimulation by HIV viral antigens alters $\mathrm{T}$ cell regulation of $\mathrm{B}$ cells which are transformed to malignant plasma cells [10].

Another postulated factor is interleukin-6 (IL-6), secreted from bone marrow stromal cells, which stimulates the growth of plasma cells as a paracrine mechanism. Human Herpes Virus-8 (HHV-8) has the ability to produce viral IL-6 (vIL-6), a human homolog of growth factor for plasma cells, which may perpetuate the growth of neoplastic plasma cells in HIV-infected individuals who are co-infected with HHV-8 [11].

The association of $\mathrm{HCV}$ infection with multiple myeloma is more controversial. Among the hematological disorders, monoclonal gammopathies rarely occur in patients with chronic HCV infection. It is speculated that HCV is lymphotropic and the mechanism which contributes to the pathogenesis of B cell nonHodgkin lymphomas (NHL) may also play a role in the development of multiple myeloma in HCV-infected populations (Figure 4) [12]. Thus, it is a relatively weak association between HCV infection and multiple myeloma. It is also of interest to note that monoclonal gammopathy, if present, is more prevalent in patients with HCV genotypes 2a and 2c [13].

To the best of our knowledge, this is the first reported case of multiple myeloma in a patient with HIV-HCV coinfection. There are several unique characteristics in our patient. First of all, she is older than the average age (33 years) of HIV-positive patients with multiple myeloma. Secondly, the clinical course of multiple myeloma in our patient was relatively less aggressive than the course usually noted in HIV-infected patients. Thirdly, her HIV infection was well-controlled, and there was no parallel progression of multiple myeloma with HIV infection to AIDS. Lastly, her HCV genotype was 1a, which is not one of the most commonly observed genotypes $(2 \mathrm{a} / 2 \mathrm{c})$ in HCV-infected patients with multiple myeloma.

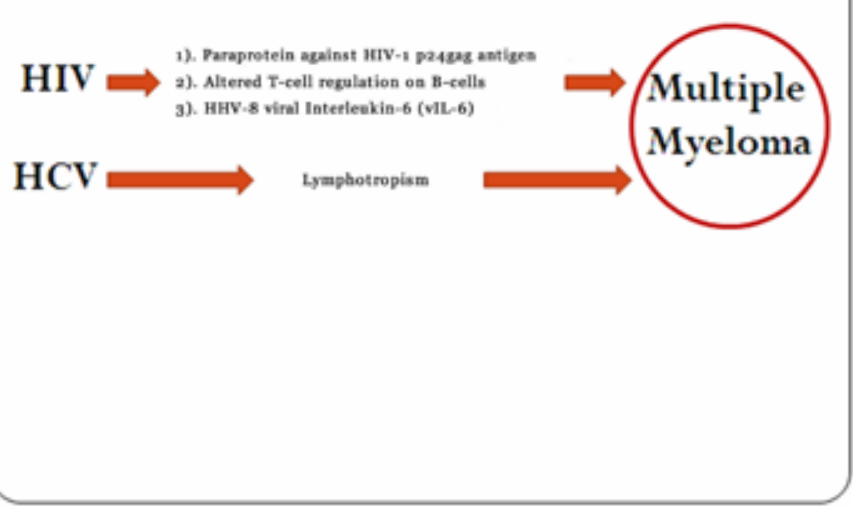

Figure 4: A schematic diagram of proposed major pathogenetic mechanisms of multiple myeloma in patients with HIV-HCV co-infection (see text for details). HHV-8 - Human Herpes Virus-8.

\section{CONCLUSION}

In conclusion, chronic infection with human immunodeficiency virus (HIV) and/or hepatitis C virus (HCV) appears to increase the risk of developing multiple myeloma, although their oncogenic role has been less established. Our case highlights that dual HIV and HCV infections may possibly have an additive effect that drives this oncogenic process leading to multiple myeloma. Further research is warranted to establish a pathogenic causal relationship. Nonetheless, providers should keep in mind that multiple myeloma may occur in HIV-monoinfected or HIV-HCV co-infected patients, especially when serum gammopathy is present. 
with hepatitis C virus infection. Haematologica 1998 Oct;83(10):946-8.

\section{Author Contributions}

Zaw Min - Conception and design, Acquisition of data, Analysis and interpretation of data, Drafting the article, Critical revision of the article, Final approval of the version to be published

Zipporah Krishnasami - Conception and design, Acquisition of data, Analysis and interpretation of data, Drafting the article, Critical revision of the article, Final approval of the version to be published

William J Cook - Conception and design, Acquisition of data, Analysis and interpretation of data, Drafting the article, Critical revision of the article, Final approval of the version to be published

Martin Rodriguez - Conception and design, Acquisition of data, Analysis and interpretation of data, Drafting the article, Critical revision of the article, Final approval of the version to be published

\section{Guarantor}

The corresponding author is the guarantor of submission.

\section{Conflict of Interest}

Authors declare no conflict of interest.

\section{Copyright}

(C) Zaw Min et al. 2013; This article is distributed under the terms of Creative Commons attribution 3.0 License which permits unrestricted use, distribution and reproduction in any means provided the original authors and original publisher are properly credited. (Please see www.ijcasereportsandimages.com/copyright-policy.php for more information.)

\section{ACKNOWLEDGEMENTS}

We would like to extend our thanks to Dr Victoria Johnson and Dr Edward W. Hook, III, for their support and suggestions on the submitted manuscript.

\section{REFERENCES}

1. Shiels MS, Pfeiffer RM, Gail MH, et al. Cancer burden in the HIV-infected population in the United States. J Natl Cancer Inst 2011 May 4;103(9):753-62.

2. Cooley TP. Non-AIDS-defining cancer in HIVinfected people. Hematol Oncol Clin North Am 2003 Jun;17(3):889-9.

3. Lewden C, Salmon D, Morlat P, et al. Causes of death among human immunodeficiency virus (HIV)infected adults in the era of potent antiretroviral therapy: Emerging role of hepatitis and cancers, persistent role of AIDS. Int $\mathrm{J}$ Epidemiol 2005 Feb;34(1):121-30.

4. Pérez Sánchez I, Rivera Redondo J, García Monforte A, et al. B-lymphoproliferative disorders in patients
5. Domingo JM, Romero S, Moreno JA, Domingo JA, Callén L, Gutiérrez M. Hepatitis C virus infection and mixed cryoglobulinemia in patients with lymphoproliferative diseases. Haematologica 1999 Jan;84(1):94-6.

6. Dezube BJ, Aboulafia DM, Pantanowitz L. Plasma cell disorders in HIV-infected patients: From benign gammopathy to multiple myeloma. AIDS Read 2004 Jul;14(7):372-4, 377-9.

7. Israel AM, Koziner B, Straus DJ. Plasmacytoma and the acquired immunodeficiency syndrome. Ann Intern Med 1983 Nov;99(5):635-6.

8. Pouli A, Lemessiou H, Rontogianni D, et al. Multiple myeloma as the first manifestation of acquired immunodeficiency syndrome: A case report and review of the literature. Ann Hematol 2001 Sep;80(9):557-60.

9. Konrad RJ, Kricka LJ, Goodman DB, Goldman J, Silberstein LE. Brief report: Myeloma-associated paraprotein directed against the HIV-1 p24 antigen in an HIV-1-seropositive patient. N Engl J Med 1993 Jun 24;328(25):1817-9.

10. Fiorino AS, Atac B. Paraproteinemia, plasmacytoma, myeloma and HIV infection. Leukemia 1997 Dec;11(12):2150-6.

11. Rettig MB, Ma HJ, Vescio RA, et al. Kaposi's sarcomaassociated herpesvirus infection of bone marrow dendritic cells from multiple myeloma patients. Science 1997 Jun 20;276(5320):1851-4.

12. Lakatos PL, Fekete S, Horanyi M, Fischer S, Abonyi ME. Development of multiple myeloma in a patient with chronic hepatitis C: A case report and review of the literature. World J Gastroenterol 2006 Apr 14;12(14):2297-300.

13. Andreone P, Zignego AL, Cursaro C, et al. Prevalence of monoclonal gammopathies in patients with hepatitis C virus infection. Ann Intern Med 1998 Aug $15 ; 129(4): 294-8$. 
Access full text article on other devices

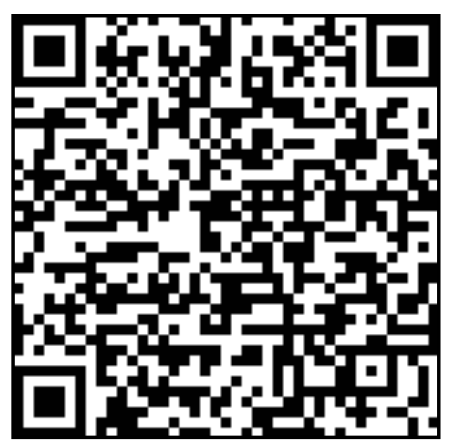

Access PDF of article on other devices

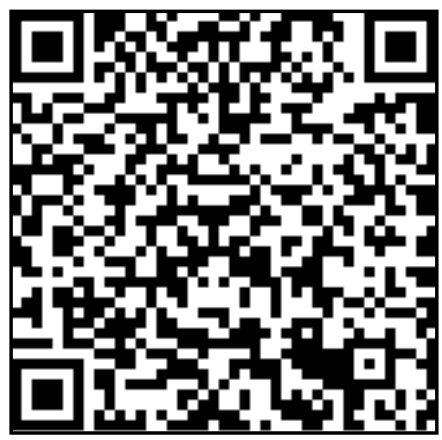

